\title{
Øst for paradis
}

\author{
Ulf Peter Hallberg
}

„Se nu forflygtiges de

Aasyn og steder samt selvet, der elsked dem efter evne,

For at genopstaa ny og forklarede $i$ et andet monster."

T. S. Eliot

(På dansk ved Kai Friis Møller)

Flanøren går over Ringstrasse, der skiller Wiens indre by fra yderverdenen. Han sukker irriteret; den brede boulevard dur ikke at flanere hen ad. Den har snarest karakter af befæstningsanlæg: magten indenfor mod masserne udenfor. Gaden grænser op til Heldenplatz, den arkitektoniske drøm om den absolutte magt. Omringet af hestedroscher, der synes massefremstillet til at passe ind på postkort, synker han hen $\mathrm{i}$ tanker.

I I913 modtog Sigmund Freud et brev fra skattemyndighederne. De udtrykte deres forundring over, at Freuds indtægter ikke var større, „da alle og enhver ved, at Deres berømmelse strækker sig langt ud over landets grænser.“ Freud svarede tørt: „Professor Freud føler sig beæret... Det er første gang, at regeringen tager notits af ham, og han udtrykker sin påskønnelse. Kun på ét punkt er han ikke indforstået med skrivelsen, nemlig at hans berømmelse skulle strække sig langt ud over Østrigs grænser. Den begynder ved grænsen.“

Den ligegyldighed og foragt, som den østrigske stat har vist sine førende kulturpersonligheder, har sat sig rige spor i den litteratur, flanøren med glæde har genkendt sig selv i. Det er muligt at følge de gensidige udfald og provokationer fra Karl Kraus via Ernst Jandl til Thomas Bernhards lakoniske Østrig „Europas toilet“. Landet er altid blevet negativt defineret, og der er et særligt begreb for det, som ikke findes $i$ de fleste andre lande: antihjemstavnslitteratur. Der er tilmed dem, der hævder, at Østrig ikke eksisterer, men at landet, og især byen Wien, siden
1918 har hengivet sig til en pragtfuld efterligning af, hvad der tidligere er produceret, med tilskud af altysk hengivelse og from glemsel.

Var det ikke denne Menasse, der sagde, at byen har trukket sig tilbage fra historien, samtidig med at den lever af sin musealitet? Han haster af sted gennem den indre bys konglomerat af sprosset historicisme, et filter af banker, Mozartskilte og historiske henvisninger; han sveder, en parodi på sine klassiske navne, den elegante repræsentant for livsleden, som stolt svingede med sin spadserestok og gav pokker i samtiden. Hvor alting er blevet anderledes!

Da flanøren føler sig dybt knyttet til Wiens kultivering af passiviteten, ser han sig selv som en forskningsrejsende, der omsider har nået målet for sin passion. Derpå fyldes han af mismod; cafeerne byder på en luksusrenoveret overgangsstemning, der hos ham udløser en mytisk vantrivsel, langsomt men sikkert forstærket til mystisk afmagt. Han oplever det som en ufrivilligt vanærende iscenesættelse ønskelitterat eller turistoid - når han på Café Central tager skrivetøj og en bog frem ved siden af en dukke i helfigur forestillende Peter Altenberg. Kun på Café Hawelka har han kunnet drikke en kop kaffe uden at skamme sig over for sig selv og fortiden. Dér er cafeen! Han slår døren op og trænger gennem tobakstågen hen til forfatteren Robert Menasses bord.

Hvad husker han af deres samtale $i$ Winterfeldtstrasse i Berlin? Beretningen om hvordan den unge Menasse indespærret på en kostskole læste romaner om natten med en lommelygte under dynen. At være udstødt og derfor opdigte en anden verden. Hvordan han byttede alle værdigenstande - chokolade, gaver og slik - for batterier, der gjorde det muligt at læse sig bort fra kostskolen. Et ungt menneske, der fuldt af harme smed Musils Den unge 
Törless fra sig, fordi romanens kostskoleverden forekom ham så harmløs sammenlignet med hans egen. Törless var en privilegeret, der endog kunne forlade kostskolen for en erotisk eskapade! Følelsen af ødelæggelse hos hans nutidige efterfølger; lummerheden $\mathrm{i}$ den homoerotiske sovesalsverden. To lange strimer på ryggen efter læderremme.

Hvorfor er flanøren så nysgerrig efter alle disse livshistorier; hvordan kan det være, at han udvikler så stærk en nærværsfølelse, når nogen forsøger at konstruere en forståelse af sin fortid? Hvorfor oplever han intuitivt, at visse mennesker forholder sig troværdigt til deres egen historie? Står menneskets livsenergi i relation til denne biografiske glødetråd? Hvordan skal han vide det? Te, han vil have te.

Han husker, hvordan Menasse fortalte om sin første roman og den forestilling, at hvert menneske behøvede at have syv liv til sin rådighed. Naturligvis syv; et til at forberede sig på sit livsværk, et til at udtænke det, et til at skrive det, et til at... Hvad var egentlig de andre mere levende liv for nogle, og er de mere levende?

- Jeg kan ikke huske det mere, siger Menasse. Alt det dér havde at gøre med min følelse af håbløshed i halvfjerdserne i Wien. Alt var præget af det såkaldt nye venstres pålæg. Jeg var en svamp, der sugede alt til sig, og jeg forsøgte hele tiden at vride svampen ud i min store roman, som det aldrig lykkedes mig at afslutte. Den skulle hedde „Hovedvemod“, og i den ville jeg give et tidsbillede. Jeg blev til sidst desperat og udstedte en slags skriveforbud mod romanskriveriet ved at forfatte en doktorafhandling om „Outsideren som type i litteraturen.“ Jeg skrev om Hermann Schürrer, en slags Wienbohemens enmandsforetagende. Han havde ry for at være en forsumpet alkoholist, men da jeg besøgte ham, drak han kun te. Jeg indså, at mytedannelse er uhyre vigtig på det litterære marked. En af grundene til, at jeg selv kommer til at lide nederlag, er min manglende evne til at stilisere mig over for omverdenen.

- Man forsøger at befri sig ved at flygte til udlandet, over mørke vande, indskyder flanøren helt uventet.

- Da jeg kom til Brasilien i I980, begyndte jeg på en tusindsiders romantrilogi. Jeg ville nedskrive alt, hvad jeg havde lært og levet for at gå fuldstændig op i romanen. Jeg ville forsøge at få en tidsfølelse eller en bevidsthed til at fremtræde. Da jeg ikke havde nogen historie eller egne erfaringer, oplevede jeg stadig mig selv som en svamp. Det eneste, der eksisterede, var det, der strømmede mod mig. Og jeg tænkte simpelt hen: det må blive mit tema.

- Var det din biografiske samtidsfølelse?

- Ja, det var den tidsfølelse, der gik gennem mig.

- I Wien taler man uafbrudt om postmodernitet, trygt nedsunket $\mathrm{i}$ hynderne på en sløvet verden, der ikke kan holde modsigelser ud.

- São Paulo betød en oplevelse af, hvordan det modsætningsfulde flyder sammen, fordi forskellige elementer, foreteelser og etniske grupper eksisterer absolut parallelt. Nøjagtig ligesom Berlin er det en grim by, hvori skønhed pludselig kan udvikle sig, fordi du altid kan overskride grænser. I den brusende metropol São Paulo gik det op for mig, at skønhed udvikles ved bevægelse.

- Wien er snarere et demonstrationsobjekt, fikseret og lamslået.

- Hvis du bor i São Paulo, har du adgang til hele verden uden at rejse. Nye verdensdele grænser op til næste kvarter; alt eksisterer samtidigt: kulturer, tilstande og egenskaber af de forskelligste slags.

- Var der følgelig forskellige tidsplaner, som lagdelte svampen Menasse, én før, én i og én efter São Paulo?

- Ja, men det, jeg lærte i Brasilien, var, at der var en mulighed for at forene eller kombinere disse forskellige personer, disse luftige svampe. I São Paulo forstod jeg, at man kan kombinere modsigelser og dermed forhindre den kvælende følelse af sønderrevethed. Man kan give det modsætningsfyldte en slags dynamik. Min snævre kostskoleverden blev sprængt af São Paulos uendelige åbenhed. Jeg havde forladt min celle og kunne føle mig hjemme overalt. Skriveriet er et spil, der handler om at skabe sammenhæng i de mest kaotiske forhold, og jeg kan spadsere afslappet gennem Wien nu uden at behøve at mumle: Wien, Wien, Wien. Det er lykkedes mig at bryde ud af kostskoleverdenen.

- Der er jo en slags emnets kannibalisme; hvis det ikke lykkes dig at skrive dig ud af dine tvangstanker, 

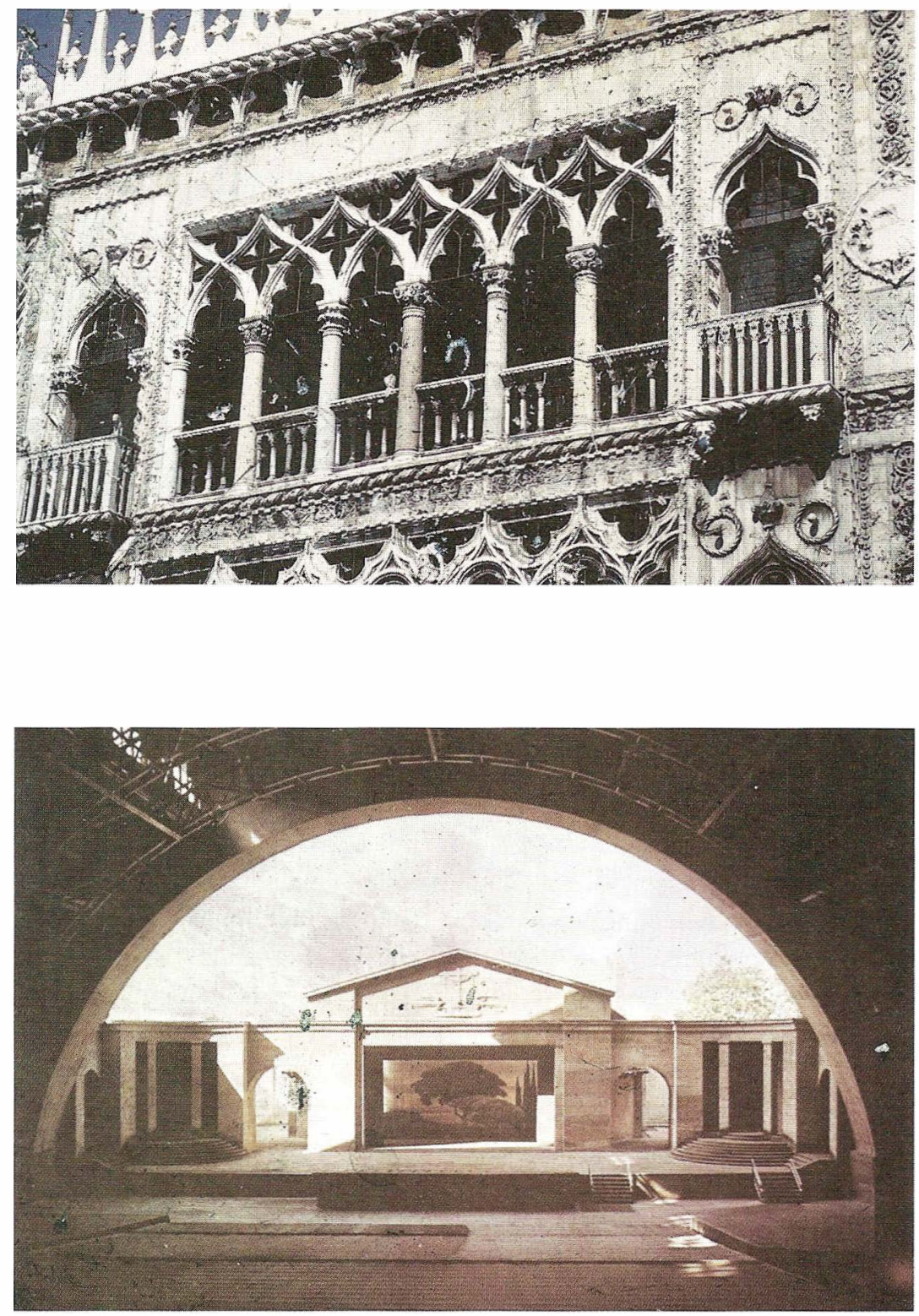
gennem dine neuroser, hvis de ikke kan kanaliseres til en fortællerstrøm, flyder du en skønne dag selv op som et søndertygget, forrådnet lig.

- Det er forfatterkannibalismen, det vil sige at blive ædt op af sig selv. Man må fodre sig med noget andet. Jeg må mætte kannibalen $\mathrm{i}$ mit indre ved at udforske emner, der ikke står i forbindelse med min person. Jeg må træde ud af mig selv.

- JEG SKRIVER I TREDJE PERSON SINGULARIS, råber flanøren pludselig. DET GIVER MIG EN FØLELSE AF SIKKERHED. JEG HÅBER IKKE, JEG SNART SKAL DØ.

Menasse betragter ham venligt, som om han venter på en fortsættelse. Flanøren sukker og lader blikket glide hen over cafégæsterne. Samme slags angst?

- Du bruger betegnelsen transvestisme om Østrigs historiske erfaring med to gange at være blevet slynget ud af sammenhænge, som landet følte sig hjemme i - det habsburgske dobbeltmonarki og det stortyske, nazistiske rige.

- Analysen af ens eget land er til stadighed blevet sat på aftægt, fordi det netop er tvivlen, man betvivler. Med henvisning til Donaumonarkiets sidste tid og den første republiks skæbne distancerer man sig i Østrig fra analyse og problematisering, med den motivering at en stat går under, hvis man ikke tror på den. Det, der konstituerer en statsdannelse, der holdes sammen på den måde, er følgelig, med Robert Musils udtryk, en permanent overgangstilstand, en diffus egenskabsløshed - og en fællesskabsfølelse, der baserer sig på hvert menneskes modvilje mod ethvert andet menneskes bestræbelser.

- Så er bestemmelsesstedet med andre ord Europa og ikke bare Wien. Men det er en gammel hjemløshed.

- At være østriger vil sige at have en nedarvet eksilfølelse. Mine forældre emigrerede under nazistperioden, og jeg kan den dag $\mathrm{i}$ dag gribe mig selv $\mathrm{i}$ at længes efter at høre hjemme et sted. Jeg tror, jeg skrev om Østrig for at klargøre spørgsmålet for mig selv. Mine forældres generation oplevede fire systemskifter, hvilket førte til en utrolig skræk for identitet.

- Somme tider føles det, som om man kun kan udtrykke kærlighed til noget ved hjælp af kritik.
- Der er en latterlig længsel efter at føle sig hjemme, der går som en rød tråd gennem mine bøger. Det vrimler med personer, der uafladeligt forsøger at få sig til at blive hjemmehørende. Tag for eksempel den jødiske far i Selige Zeiten, som hele aftenen emfatisk synger julesange - selv om han er alene med sin familie - som om han vil vise, hvor fantastisk den lille jøde har assimileret sig i det katolske land. Også i romanen Schubumkehr vrimler det med personer, der ikke har det godt og krampagtigt forsøger at fremkalde en følelse for hjemstavnen. Der er en sø med bredder, træer, græsplæner, og det hele bliver fragtet bort, træer og græsplæner plantes om, og sten anbringes af landskabsarkitekter, så de kan ligge der smukt befriet for mos. Man omskaber naturen til hjemstavnsnatur for at kunne tage imod turister $\mathrm{i}$ den.

- Og det sker i 1989, i en lille landsby på grænsen til Tjekkoslovakiet.

- En mand fra et reklamebureau kommer ud for at planlægge en brochure, og da han ser jagttårnene langs skråningerne, siger han: I skal bygge flere jagttårne, for når turisterne kommer og făr øje på et jagttårn, vil de forvente at se en flok rådyr komme ud af skovbrynet, turister elsker den slags; så I skal bygge så mange jagttårne som muligt. Og efterhånden åbnes grænsen, og vagttårnene på den anden side forsvinder, men en ny grænse af jagttårne står klar. Romanen er også en grænseovergang: spørgsmålet er nemlig, hvordan man skal få orden i fortællingen, når alting går $\mathrm{i}$ uorden. Hvordan skal jeg kunne fortælle sammenhængende historier, når alting sønderdeles i småpartikler. Det handler om den fortælletekniske grænse og tillige om den indre grænse. Hvordan kan det være, at de indre grænser er så mærkbare, når de ydre grænser åbnes? Da min romanhelt i Schubumkehr hen mod slumingen sidder i lufthavnen og venter på sit fly, åbnes grænsen pludselig, og kamerahold fra hele verden filmer, hvordan grænselandenes to udenrigsministre afmonterer jerntæppet. De råber om og om igen til udenrigsministrene: én gang til! $\mathrm{Og}$ de to udenrigsministre tvinges til at gentage scenen adskillige gange, indtil tv-holdene har deres dokument over denne historiske begivenhed. 
- Wien er den perfekte teaterloge, ler flanøren.

- Det er bekvemt, når begivenhederne indtræffer i Tchad eller Chile, men ikke når verdenshistorien slår til ved vores egen grænse. Stemningen i Østrig i 1989 var: ja, her er alt jo, som det skal være, men hvem ved, om ikke disse omvæltninger forårsager uorden her i landet. Og samtidig snurrede tildragelserne hurtigere og hurtigere; det er det år, jeg har forsøgt at beskrive. Lang tid efter har jeg spurgt mig selv, hvorfor jeg ikke tog det første det bedste tog til Berlin, da muren faldt. Hvis det var sket på klassisk vis, ved at vi fandt ud af det $\mathrm{i}$ eftermiddagsbladene, havde man måske kastet sig på toget. Men i vor tid betragter man historiske begivenheder, som om man sidder og ser en film om New York. Man rejser sig jo ikke op midt $i$ forestillingen og flyver til New York!

Flanøren står sammen med Menasse på et blæsende gadehjørne. Tiden er inde til at sige farvel.

- Ingen af dem, jeg har talt med i min tid i Wien, har i de seneste år været i Bratislava, der ligger tres kilometer herfra. De fleste har aldrig været der. Slorakiet synes $\mathrm{i}$ wienernes øjne at være en metafor for fiasko.

- Wien har altid været endnu mere indemuret end Berlin. Det frygtelige var, at man ikke kunne male graffiti på Wienmuren, fordi den var usynlig. Sådan en mur kan man ikke rive ned.

I Menasses iris det hvide, støvhvirvlende lys fra São Paulo.

- Østrig har ikke andet end kirkegårde og en kapucinerkrypt og ikke noget Pantheon. Det er som det skal være. De ligger alle under græsset: Beethoren, Bruckner, Stifter, Raimund, Nestroy, Grillparzer - at repræsentere det østrigske vil sige at blive mishandlet og misforstået $i$ sin levetid og efter sin død være upåagtet for så ved et enkelt jubilæum at blive hævet op af glemslen. Vi ses.

I kunstbygningen ved Karlskirken har man sammenstillet „billeder af døden“, hvilket føles magtpåliggende. „Døden er det spejl, hvori viden betragter livet,“ som Foucault skrev. Flanøren står længe foran 1800-talsmaleren Fritz Amerlings portræt af hustruen og derpå sønnen, på dødslejet. Disse feberblanke blik langt borte fra, dette vemod ved synet af noget, der aldrig kommer tilbage! Er det ikke sådan, nutidsmennesket tvinges til at betragte livet $\mathrm{i}$ byer som Wien? Ved salens ene endevæg har man opstablet dødsmasker af byens store mænd: Anton Bruckner, Egon Schiele, Arthur Schnitzler, Peter Altenberg, Franz Grillparzer, Hugo Wolf... Karl Kraus ser ud som en glad, rund kineser; Gustav Mahlers halsmuskler er hårdt spændt i kamp. De ser begge mærkeligt levende ud.

På en særlig hylde ved udgangen står der en lille æske med påskriften ,Kuvert med resterne af Ludwig van Beethovens ligdragt, samt hovedhår tilhørende Franz Schubert og træsplinter fra dennes kiste. “ Det er alt.

Der er noget ved forfatteren Franz Schuh, som fortjener betegnelsen usandsynligt. Spørgsmålet er, om det er den imposante krop, hjerteneurosen eller hjernen. Selv beskriver han sin fremtoning på følgende måde: ,Jeg er hovedsagelig et åndeligt menneske, det vil sige min krop er ikke i form, men mit hoved summer som en projektor $i$ en hjemmebiograf."

Franz Schuh er født i 1947 og tilhører en generation af tysksprogede intellektuelle, der formedes af doktor Hegel, doktor Benjamin og doktor Adorno. Det hed sig om Thomas Bernhard, at han efter at have talt uafbrudt i ti timer på spørgsmålet om opbrud og afslutning kunne svare: „Lad os tale to timer til, så det bliver fulde tolv!“ Flanøren har samme fornemmelse med Schuh. Et spørgsmål om hans doktorafhandling om Hegel fører til et exposé over det akademiske Østrigs lukkethed, til en kritik af tressernes heideggerianisme og til hans modvilje mod „statspensionisten“, det vil sige embedsfilosoffen. Hans egen udvikling indbefatter et selvvalgt brud med det akademiske og et fuldstændigt sammenbrud efter en måneds arbejde $i$ en folkeskole $i$ en af Wiens forstæder.

- Jeg ville bringe viden derud. Men det var så udsigtsløst, så antiintellektuelt og dannelsesfjendtligt, at jeg omgående blev alvorligt syg. Jeg tilbragte tre måneder derude, to måneder med hjerteneurose, 

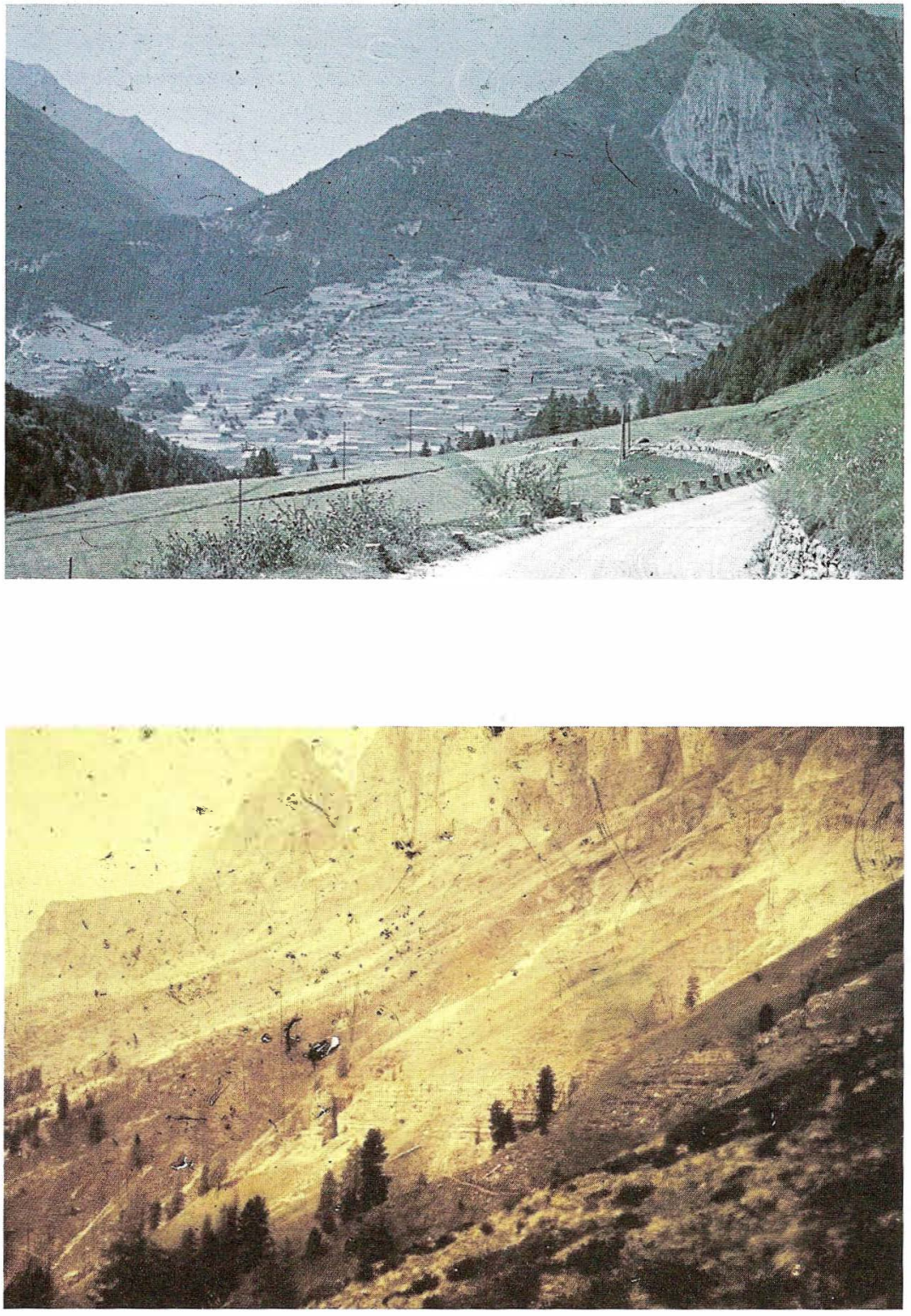

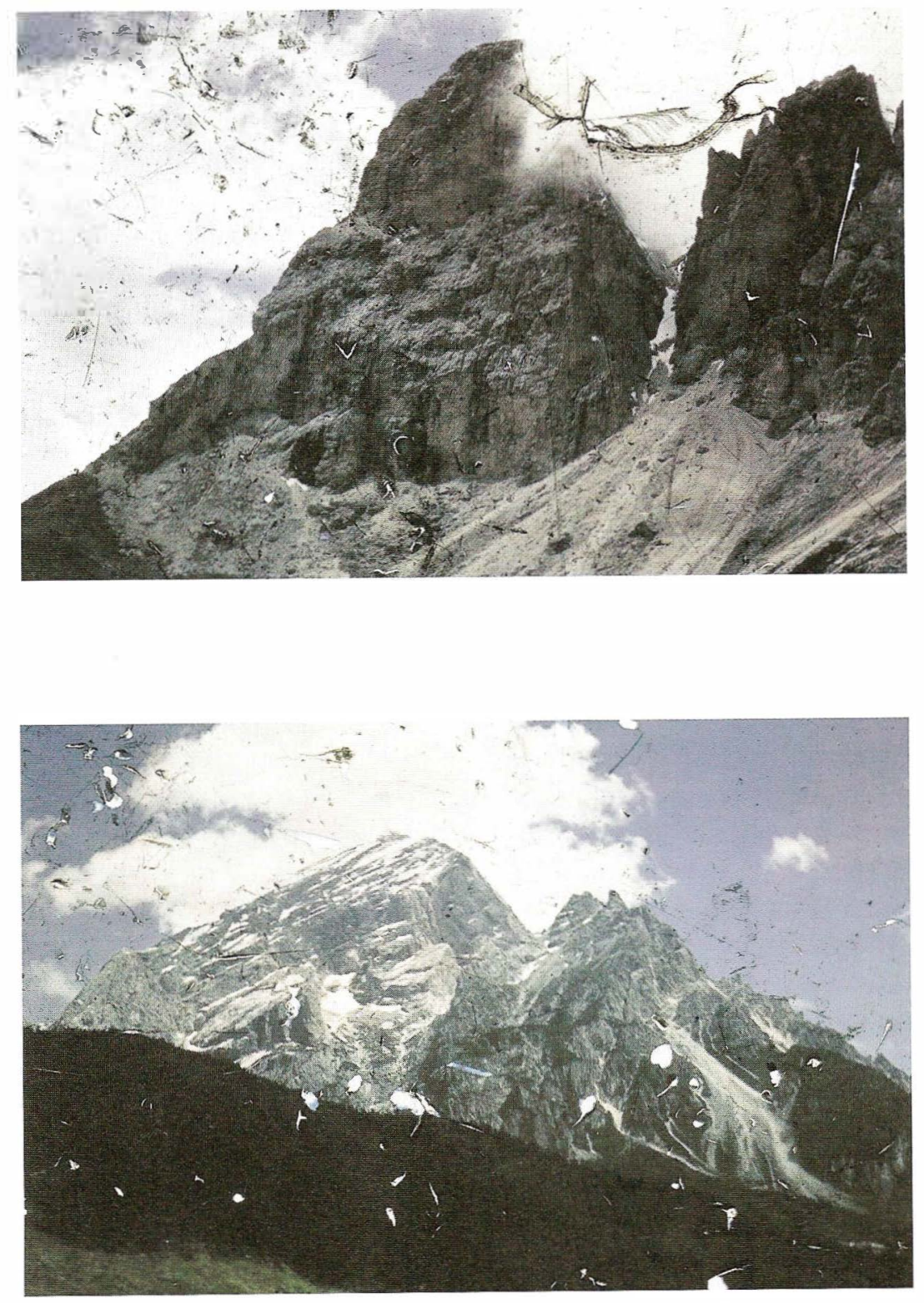
hvilket vil sige at man hver dag bilder sig ind, at man får et hjerteindfald. Årsagen til dette var den forste måned, og resultatet blev et halvt år som medicinerende rekonvalescent. Det var min psykoneurotiske initiationsrite $i$ samfundet.

Flanøren befinder sig i Franz Schuhs arbejdslejlighed $\mathrm{i}$ Werdertorgasse $\mathrm{i}$ Wiens indre by, og denne forelæser midt $i$ en oase af bøger eller stirrer stift på flanøren, samtidig med at hjernen synes at smage på svarenes mulige omfang i tid og rum.

- Jeg stammer fra en kommunistisk familie. Min far trådte ud af partiet efter Ungarnsoprøret. Men det var et livsmiljø, hvori man ikke fortolkede heroismen eller tilværelsens ulidelige tyngde ved hjælp af en ren videnskabelighed eller abstraherende fakta à la Heidegger, men dialektikken spillede en rolle som kampmetafor.

- I øjeblikket præges Østrig af en fatal mangel på kamplyst. Man er parat til at finde sig $i$ alt og have det godt $i$ en individualiseret eller totaliseret ensomhed som masseeremit. Det er som lammelsen efter en spændingstilstand, en slags uigennemtrængelig glasvæg mellem menneskene og virkeligheden. I det tyske sprogområde kan man samtidig definere den ændrede forfatterholdning som en eliminering af en kritisk, aggressiv holdning til fordel for en kunstreligion. Dette i en tid med ekstreme modsætninger. Mængden af umenneskelige væsener er tiltagende på alle samfundsområder, og de bidrager til at udvikle et destruktivt potentiale i velfærdssamfundet, som skaber frygt. De etisk-moralske konsekvenser er af en sådan art, at de konservatives forsøg på at støbe traditionelle værdier over krisens esse fremstår som yderst patetiske, fordi samfundsformen umuliggør og tilintetgør netop disse værdier.

- Hvilken funktion har skriveriet da i denne hærgede verden?

- Det er en neurotisk situation: når et menneskes narcissisme munder ud i produktion af ordmasser. Men skriveriet har for mig noget at gøre med en fremmedhed i forhold til verden, og disse erfaringer er også historisk betingede. I mit tilfælde havde det at gøre med en ekstrem ensomhed $i$ alderen fra tolv til atten. Mit udgangspunkt er tvivl. Inden man begynder at skrive, identificerer man sig ofte med en forfatter, i mit tilfælde Karl Kraus. Han stod ikke fremmed over for sig selv, men hos ham kunne jeg læse om min egen fremmedhed. Men dette var længe før, jeg gjorde mig skyldig ved eget skriveri.

- Hvorfor taler du om skyld?

- Det er min egen tragiske, halvironiske betragtningsmåde, som har sin oprindelse hos Karl Kraus og i den kendsgerning, at så mange føler sig uskyldige og plaprer løs offentligt. Det er en tradition af dyb skepsis $\mathrm{i}$ forhold til ethvert skriveri. Jeg har ingen tillid til den intellektuelle. Paradokset er, at den ,renhed“, der dermed efterstræbes, ikke kan opløses ved, at man ikke skriver. Skriveriet er nemlig også et forsøg på at bibeholde en sfære, inden for hvilken man er levende. Det betyder, at man ikke kan nøjes med spidsborgerens bekvemme mistro over for intellektuelle ytringer. At være levende uden at kæmpe er utænkeligt. Problemet er, at mange kunstnere og forfattere kun kan være levende $\mathrm{i}$ deres kunst. Blandt mange skrivende er der for tiden en triumferende, afslørende modvilje mod erfaringen. Naturligvis kan man ikke besvare spørgsmålet „Hvem skriver?““ med et simpelt ,Jeg.““ Problemet er bl.a., at jeget end ikke er herre i sit eget hus. Det fremtidige menneske synes snarest at være egenskabsløst. Det store eksempel er Musils Manden uden egenskaber. Hovedpersonen Ulrich står for en egenskabsløshed, som i stadig højere grad er kommet til at præge det 20. århundredes menneske. Men på det personlige plan behøver den ikke at fortolkes udelukkende negativt.

- Det siges jo om Ulrich, at han ikke bare er uden egenskaber men samtidig kan have alle egenskaber, indskyder flanøren.

- Det er et vigtigt aspekt af legens eller spillets betydning for identiteten, som de moralistiske kritikere af postmodernismen ikke har opfanget. Det er nemlig alt andet end et vilkårligt spil. Det er, som når noget ikke er rigtigt $\mathrm{i}$ et kærlighedsforhold. Som krav bliver kærligheden absurd, hvad elskende ikke forstår. De kræver altså en hengivenhed, som ikke kan eksistere, hvis ikke den indfinder sig af sig selv. Jeg har altid godt kunnet lide Martin Walsers definition: „Forfatteren er den, der forandres ved at skrive.“ Den gør det muligt at lægge mærke til, at 
de fleste forfattere ikke skriver for at forandre sig, men for at forblive den samme.

Da flanøren strejfer hjemad gennem Wiens tomt genlydende stræder, mindes han doktor Benjamins karakteristik af Karl Kraus: „I en ældgammel rustning, forbitret hånleende, danser han sin krigsdans på det tyske sprogs gravhvælving, et kinesisk afgudsbillede, som $\mathrm{i}$ begge hænder svinger de dragne sværd.“

$\star$

Fra det forfaldne stikspor Søndre Station i Wien tager flanøren toget mod øst. Der hviler noget snavset og forkomment over bygningen, med sammenkrøbne grå figurer indhyllet $\mathrm{i}$ sjaler $\mathrm{i}$ alle hjørner, og efter afrejsen føles det, som om det næsten tomme tog med sin majoritet af toldpersonale og billetkontrollører ruller ind $i$ en afvigende zone, et stillestående sletteland, der pludselig er blevet pløjet op og har røbet fortidens levninger - tørret lort, rustne mønter og revnede pistolkolber.

Den lille skare af udenlandske rejsende overrumples allerede $\mathrm{i}$ bussen ind til Bratislavas centrum, da en af passagererne med en kunstfærdig pantomime pludselig udfører Stålmandens forvandlingsnummer og afslører tjenesteuniformen og kontrollørskiltet under dynejakken. Manden har ligget på lur og indkasserer med et lille underfundigt smil bøderne for busrejse uden gyldig rejsehjemmel.

Er det en rest af det lumske kontrolsamfund eller en nødvendig strategi for at informere det af staten slappede individ om visse elementære pligter? Det minder mest om hastighedskontrollerne i det daværende DDR - velorganiserede wild-east-baghold for at fange den ubekymrede dagdriver, vestturisten.

I det gamle Bratislavas mylder af stræder fører flanørens vandring tilbage $\mathrm{i}$ tiden, til forhistorien, til huse, ruiner og tegn, der minder om det stormähriske rige og den følgende, ungarske overhøjhed. Ingen steder forekommer historien ham så tydelig som $i$ det lille antikvariat $\mathrm{i}$ Klariska, hvor de håndkolorerede postkort indeholder hilsener fra Sarajevo I9I4, lykønskninger fra den lune mellemkrigsstrand i Trieste eller soldaterhilsener hjem fra det klerikal- fascistiske slovakiske regimes samarbejde med nazisterne fra 1939 til 1945.

I de gamle håndindbundne bøger sporer han udviklingen fra det slovakisk farvede „bibeltjekkisk“ i I60o-tallet til Lúdovít Štúrs skriftsprogsreform i I843; hvordan det af embedsverdenen og øvrigheden hundsede skriftsprog trods alt overlevede habsburgepokens „magyarisering“ og den tjekkiske overlejring i I900-tallet for først $i$ og med den halvhjertede føderation $\mathrm{i} 1968$ at blive ligestillet embedssprog.

Borgen i Bratislava renoveres, magtens insignier males om. Flanøren falder hovedkulds ned i et umarkeret bygningshul på vej op til slotsruinens udsigtspunkt. Lige så hovedkulds synes mange slovakker at være blevet slynget ud i selvstændigheden. Det seneste års springagtige udvikling åbenbarede for mange retorikkens paradokser og den politiske begrebsmaskerade, en udviklingskæde fra tanken om føderation, via udtrykkene autentisk føderation, kooperativ føderation, konføderation, personalunion til det magiske udtryk ,international subjektivitet" - som signalerede selvstændigheden.

Flanøren vil vide, hvordan man fortolker sin egen historie i lyset af forandringerne og selvstændigheden. Han spadserer langsomt til Videnskabsakademiets litteraturvidenskabelige institut. Instituttet er opdelt $i$ to afdelinger, den slovaliske litteratur og verdenslitteraturen. Den forstnævnte afdelings leder Peter Zajac var også en af lederne af borgerretsbevægelsen Offentlighed mod vold, der modsatte sig selvstændigheden og plæderede for en konføderation. Bevægelsen blev erklæret fallit og opløst.

Det slovakiske samfund beskriver Zajac som en bølgegang mellem åbenhed og lukkethed.

- Forfattergenerationen i trediverne studerede i Prag, Moskva og Paris, derpå blev samfundet fuldstændig lukket for i nogen grad atter at blive åbnet i Dubcekæraen og derpå blive lukket igen i forbindelse med 'konsolideringen', for så at blive åbnet engang midt $i$ halvfjerdserne og fuldstændig lukket i 1979. Til sidst åbnedes det slovakiske samfund igen i forbindelse med Gorbatjovs magtovertagelse i 1985 . 


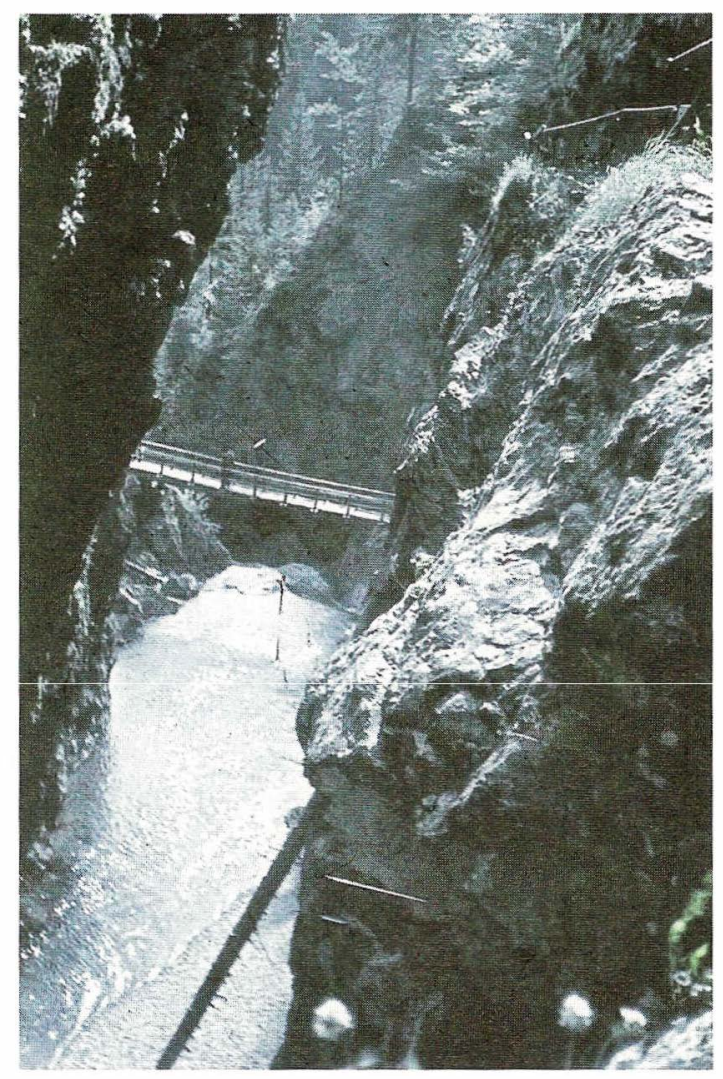


Zajac påpeger, at forskellene mellem den tjekkiske og den slovakiske litteratur er bemærkelsesværdige.

- Den tjekkiske litteratur udgøres af dissidenterne, mens den slovakiske har nydt større frihed og samtidig har en ubetydelig eksillitteratur, der kun har konserveret tidligere tendenser.

Som svar på et spørgsmål om strukturalismens indflydelse fortæller Zajac, at Jurij Lotman blev udgivet $\mathrm{i}$ tresserne, men at udgaverne lidt efter lidt blev inddraget. På samme tid oversattes også Roland Barthes og Michel Foucault.

- Det mærkelige er, at tressernes glade, legende postmodernisme, der medførte en opdagelse af pluraliteten og det fragmentariske, helt og holdent har skiftet karakter. Den er blevet et forhæng. Mange, der før 1989 aldrig havde turdet at tage ordet postmodernisme i munden, snakkede pludselig udelukkende om postmodernismen. Kolleger, der to uger før omvæltningen skrev om den største socialistiske digter, bearbejdede pludselig en måned senere de hvide pletter i vores litteratur i postmodernistisk ånd. Det, man nu, i den postmarxistiske æra, påberåbte sig, var, at der ikke gives nogen sandhed, kun enkeltsandheder, og det er sikkert rigtigt, når talen er om det sproglige udsagns differentiering i filosofisk forstand, men nu blev denne betragtningsmåde brugt på de seneste fyrre års historie, og enhver påberåbte sig sin sandhed. For den ene var det dissidentens sandhed, og for den anden var det den sandhed, der sørgede for, at dissidenten blev forfulgt. Sproglige simulationer havde samme sandhedsindhold som de anderledestænkendes tidligere eksistens, og pludselig havde alle været forfulgt, og et stort antal nye helte dukkede op. For mig betyder denne østeuropæiske postmodernisme en flugt fra historien.

- Jeg skelner mellem en primær nationalisme af traditionel art - som f.eks. i Sverige - og den østeuropæiske nostalgibevægelse, ,efternølernes nationalisme“, der bl.a. er blevet anført af de velorganiserede kommunister. Jeg ville altid støtte en konstitutionel, civil patriotisme, der hviler på en forfatning, men her drejer det sig snarere om ved hjælp af nationalismen at tage afsked med de seneste års demokratiseringsproces og frem for alt om at udslette fortiden. Læg mærke til, hvordan de ,store patrioter“ i Serbien siger: „Vi støtter pressens frihed, men vi bytter den ikke for vort lands frihed.“

Fortidens vrængbilleder fremtræder $i$ et utal af spejle. Zajac mener, at hvis man ikke kan skelne mellem rigtigt og forkert i fortiden, så kan man heller ikke gøre det $\mathrm{i}$ fremtiden. Han betragter nationalismen som en ideologi, hvis opgave er at maskere fortiden og konstruere et historisk alibi for kommunisterne. Spørgsmålet er ikke længere, hvad man lavede $\mathrm{i}$ fortiden, men hvilken indstilling man har til den nye stat. Og Zajac synes at være bevidst om, at hans egen borgerretslige holdning, der modsatte sig selvstændigheden, er det nye fjendebillede.

- Fremtiden umuliggøres af fortrængningen af fortiden, og der ligger en fare $i$, at man kun aktualiserer den del af forhistorien, der passer ind i de nye politiske bestræbelser. Den østeuropæiske postmodernisme fører desuden til en relativismens og pluralismens totalitarisme. I Vesteuropa kan man måske indtil videre, på en relativt stabil baggrund, lege med begreberne sandhed og løgn, men her hvor alt er utydeligt og opløst, fører den leg ikke bare til, at historisk identitet og mening forsvinder - men de negative virkninger er endnu mere konkrete og skæbnesvangre. Det er det, der er den østeuropæiske postmodernismes barbari.

På en af de få natcafeer møder flanøren den udenlandske ekspertise, konsulenter og sproglærere i diaspora. De kommer fra alle mulige kanter for at undervise, profitere eller iagttage. En af dem, øststatseksperten Chandler Rosenberg fra „Institute of Current World Affairs,“ siger: „De nye nationalstater stræber alle efter at opnå Habsburgs magt og myndighed, men kun for eget vedkommende.“ En servitrice i lårhøje læderstøvler giver flanøren en neologisme, som synes at sammenfatte den historiske situation.

- Auf Wiedersein!

Til sidst mangler der under eftersøgningen af den slovakiske identitet kun et besøg hos forfatteren Vladimír Mináč, den slovakiske litteraturs nestor. Hans romantrilogi En generation, der blev offentliggjort I958-6I, udgør et nationalepos og er et doku- 
ment over den marxistisk farvede romantraditions historieskrivning. Mínáč, tidligere medlem af kommunistpartiet, var en tid selvstændigt medlem af parlamentet i Prag for Mečiars parti; nu helliger han sig igen forfatterskabet. Han forklarer i telefonen, at han har vanskeligt ved at komme ind i centrum, men da flanøren møder den halvfjerdsårige, forekommer det ham, at han står over for en pensioneret professionel bokser uden bevægelseshæmninger. Mináč flankeres af tre unge, ivrigt skålende redaktionsmedlemmer fra avisen Pravda, der oplever et opsving. Han karakteriserer stolt sine unge frænder som det nye, anarkistiske venstre.

- De hader alt, men de kan godt lide mig.

Som så mange andre karakteriserer Mináč sit tidligere tilhørsforhold til partiet og den paradoksale kombination af nærhed og distance til centralkomiteen som en kritisk og oppositionel position. Mináč tilhører en garde, der forsvinder for altid, en sidste grandios overlevende, et storslået monument $i$ et ruinlandskab, og det han siger karakteriserer måske bedre end noget andet ideologiens og utopiens forskydning hos disse ranke, fratrædende skikkelser som altid formåede at forme tilværelsen, så den så ud til at udgøre en helhed.

- Jeg er personifikationen af slovakisk historie. Man har altid sagt om hr. Mináč, at han repræsenterer sandheden, en af de små sandheder blandt verdens store, den lille slovakiske sandhed. Jeg har levet forandringerne, og jeg har beskrevet dem. Som kommunist led jeg nederlag, men som slovak står jeg ved fremtidens rand. Det smukkeste symbol for Slovakiet er broen. Vi er hverken øst eller vest, men en syv hundrede kilometer lang bro.

På den tid var alt omgivet af et stort mørke. Prag var mødestedet mellem øst og vest, det summende samlingssted, hvor han og Anna Blume forsøgte at ophæve verdens spaltning under det legendariske maleri på cafeen, billedet af den hærgede gæst der drømmende ser over på en æterisk kvindeskikkelse, som nøgen løsiver sig fra røgtæpperne omkring bordet.
Flanøren h usker; han sị̂der på café Slavia på Smetanovo Nábřeží og ser ud over Moldau. En mand ved vinduet åbner en notesbog og begynder at skrive. Mens et regnskyl pisker mod floden taler Anna Blume med nogle gæster ved nabobordet. Flanøren forstår ikke meget og giver sig til at betragte mændene; der er noget brustent i deres øjne, en skygge af sorg som han genkender fra venner $i$ eksil. Regnen tager til, og han betragter disen over Karlsbroen - Kleinseite ses kun svagt. Pludselig glitrer det $\mathrm{i}$ efterårsregnen, solen bryder igennem og Prags skønhed rammer ham i hjertet.

Da flyver en svane op på førstemajbroen, midt $\mathrm{i}$ myldretidstrafikken. Et kort øjeblik breder den sine store, kridhvide vinger ud foran biler og sporvogne - en hvid engel i trafikkens kaos, indrammet af røde paraplyer. Derpå bliver svanen kørt over. Den slår nogle gange med vingerne mod brostenene, det er alt. Fodgængerne står rådvilde. En mand bøjer sig ned og klapper forsigtigt svanen over svingfjerene, som for at sige: „Vågn til live!“ Billedet synes frosset igen. I et sekund er dagligdagens travlhed gennemskuet: der er ingen orden at føre den døde fugl tilbage til, svaneambulancer findes ikke.

Fra den anden side af broen kommer to soldater gående. Folkemængden viger til side og de uniformerede passerer, demonstrerende en absolut ligegyldighed over for den lysende hvide fuglekrop. Men da soldaterne når til enden af broen og effektivt fjerner den hvide klump fra gadebilledet og opfordrer fodgængerne til at sætte sig $\mathrm{i}$ bevægelse igen, ser flanøren, at manden med notesbogen græder.

I skumringen bedækker disen Budas bløde bakker og de spadserende går lystent under brospændene uden at skænke de sorte hvirvler en tanke. Flanøren hengiver sig til broens atmosfære: følelsen af overgang og mellemstadium, en konstruktion i samme ånd som hans gang. Da gadelygterne tændes sidder flanøren i tovbanen og følger lysspillet ovenfra.

Han er glad over at være sluppet ud af sin bolig. Når han åbner døren til sit værelse, tvinges han altid til at gå ind i værtsfamiliens spisestue. Dér troner 
den ungarske patriark dagen lang foran sin overfyldte tallerken og sine ølkrus, mens den forskræmte hustru farer rundt som et opskræmt, husligt spøgelse. Når kvinden udmattet er faldet i søvn begynder patriarkens virkelige liv. Sammen med det identiske afkom, miniaturepatriarken, agerer han verdenskommentator. De såkaldte begivenheder flimrer forbi i et rektangulært plasticskab, som om natten fyldes af opslidsede speakerdamer med glinsende trutmunde. De kurrende stemmer afbrydes kun af patriarkens tilråb eller larmen af væltet porcelæn. Det er dette desperate fravær, flanøren flygter fra. I sine spadseretursfantasier betragter han verden som prototypen på den umenneskelige medløber, det kuede dyr, der altid vil slippe udenom. Han har en følelse af, at lejlighedens voldsomme, undertrykte spændinger gemmer et stykke partihistorie.

Han tager forstadstoget ud til Rómaifürdö og finder Péter Esterházy i den gamle familievilla; forfatteren træder ud af et værelse, der ser ud som om nogen har væltet et skrivebord og en ton papir direkte ud af en container. Esterházy arbejder på en roman der undersøger slægten Esterházys historie i Europas midte siden I500-tallet.

Flanøren føres ind $\mathrm{i}$ et tilstødende værelse, hvor han forskrækkes over sit diffuse spejlbillede. Han befinder sig i udkanten af det, der tidligere blev kaldt den neonkapitalistiske del af øst. Samfundet har rystet socialismen af sig, som en hund ryster vand af sig, skriver Péter Esterházy, selv om det altid har været svært at vide, hvor vandet hørte op og hunden begyndte.

- Rummede drømmen om Centraleuropa ikke en slags håb om evige åndelige værdier, der ville overleve alt andet?

- Jeg har altid været skeptisk. Det eneste, der er tilbage, er en fælles oplevelse af virkeligheden, en følelse af at være udleveret, prisgivet. Det har at gøre med manglen på et civilt samfund og det nøgne forhold til magten. I det er der faktisk noget fælles, fra Leipzig til Sarajevo. Det er naturligvis et negativt begreb, en mangel på noget - men det er netop manglen, der igen er fælles. Jeg troede selv, at den fælles lidelse ville være en modvægt mod gentagelse af vores historiske fortid, men udviklingen er gået i en helt anden retning.

Befandt forfatteren sig tidligere i en slags forstørret kampsituation, som fik til følge, at han overvurderede sit eget virkefelt?

- I Ungarn var fjenden ubehagelig men uinteressant. At være modstander af regimet var nyttigt men uvigtigt. For det krævede ikke stort mod. Staten var $i$ en tilstand af forrådnelse, blød som en pære. At være imod var også et fedtet pløre. Problemet nu er, at mennesker ikke vil huske, eller også vil de kun huske. I Ungarn er det særlig ubehageligt at huske, fordi det var et blødt diktatur, hvilket egentlig bare betyder, at diktaturet var muligt.

- De russiske forfattere vender tilbage til det, de kalder det sovjetiske sprogs død.

- Den død er enhver bog berørt af. Selv de, der siger, at de har undgået chiffrerede tekster. De fleste bøger, der levede af den politiske modstand, er døde. Men en del af disse bøger udøvede naturligvis en konkret modstand mod regimet, uafhængigt af forfatterne, af os.

- Jeg tiltrækkes af ironien - og frem for alt selvironien - i dine tekster. Selvironiens styrke er jo, at den antyder en mulighed for at undgå at stille sig over det, man ser eller skriver.

- Den største fare, der udgår fra staten eller magten, er ikke, at den berøver en frihed eller sætter grænser; det er, at man tager magtens døde bygninger alvorligt. Og under omvæltningen udvikledes denne alvor endnu en gang til selvbedrageri: man tog det gode samfund alvorligt.

- Den anden side af sagen ville være den alt for store alvor, hvormed mange forfattere betragter sig selv, sukker flanøren. At skrive er en tvivlsom beskæftigelse, og de interessante udøvere $i$ vor tid er ofte ironikere som Musil. De udsætter jeget for permanent beskydning.

- Det har at gøre med, at hvis man tager visse samfundssystemer alt for alvorligt, så oplever man sig selv som repræsentant. Det var og er den store fare i Øst- og Centraleuropa. For mig drejer det at skrive sig altid om en situation: jeg-vi. Hvis jeg udelukkende oplever mit jeg, så er alt personligt; på den anden side kan erfaringen kun støtte sig til mit jeg. 
Det at skrive fungerer, hvis der er en bevægelse mellem disse to poler. Det er en tankeproces, en måde at gøre erfaringer på. Jeg erfarer tingene ved at skrive. Det er en læreproces. Hvis det forbliver det enkelte jegs læreproces, er det helt uinteressant. Det er netop det, der gør en afhængig af denne komiske, ikkefungerende eller tvivlsomme relation mellem jeg og vi. At den personlige erfaring også er en erfaring for et „vi“, kalder jeg læselighed. Det er læseligt, fordi det er fælles.

- I din bog Ned ad Donau benytter du den rejsende som fænomen og romanfigur. Du skriver: „Når jeg rejser, er jeg den seendes skytsengel. Jeg søger i mig selv og i verden - og ifølge arbejdshypotesen lønner det sig ikke at skelne mellem de to - mønstre, som jeg kan måle mine erfaringer med.“

- Dér passer ordet erfaring måske ind! Problemet med Ned ad Donau var, at jeg virkelig rejste. Jeg ville være en rejsende, skønt jeg ved, at jeg er bange for at være en rejsende. Jeg er kun forfatter, men har aldrig opfattet dette „kun“ som en indskrænkning. Men som rejsende følte jeg mig koket, hvilket medforte, at netop i forholdet til den rejsende som mulighed indeholdt mit skriveri et „kun“, en restriktion.

- Du skriver, at du er uvillig til at acceptere ideen om, at historien skulle være forbi. Du bruger en sammenligning mellem floden og vandet. Forskellen er, at floden har en erindring, en fortid, en historie. „Der er ikke noget begivenhedsforløb,“ skriver du, „men der er en skæbne.“

- Det farlige hos os er trætheden, som man ser afspejle sig i alle de dystre ansigter. Man kan ikke holde ud at være alene og kaster sig derfor ind $\mathrm{i}$ et nyt gruppetilhørsforhold. Den nuværende demagogi omfatter også tidligere dissidenter: hovedredaktøren for et tidsskrift, der tidligere var rettet mod magten, forsøger i sin regeringsstilling at skaffe sig kontrol over radio og TV. Det føles som en ny Kádáræra. De vigtige dårlige bøgers tid er forbi. Det er middelmådighedens epoke: alle, der ikke har skrevet noget, undskylder sig med, at de var forfulgt.

- For mig har Manden uden egenskaber altid været et positivt begreb. Den, der ikke har nogen egenskaber, kan samtidig have alle: det ville være forfatte- rens position. I dag er problemet vel snarest, at „Manden uden lidenskaber“ er muteret til massemenneske. Du taler om en „Verden uden egenskaber“. Du skriver: „vi har ingen erfaring med og ingen ideer om, hvordan et Europa arter sig uden drømme, for så længe verden har set ud som den gør, har der altid været drømme i Europa, og disse uudslettelige drømme har for det meste fungeret som ufravigelige betingelser for Europa. Vi befinder os dér, hvor Musil slap tråden: manden uden egenskaber søger sin identitet.“ Du skriver, at det ser ud, som om vi i hundreder af år har hengivet os til tidsfordriv, og at slutpunktet er forskellige varianter af nationalisme.

- Det drejer sig om en fælles erfaring, der er borte. Men et Europa uden drømme er en selvmodsigelse. Vi er blevet bange for alle svar. Den nuværende situation kan ikke forklares, det er selve spørgsmålet. Det er som hos Wittgenstein: Når man ikke kan spørge længere, så er det svaret.

Count Esterházy farer hen ad en korridor i Videnskäbernes Akademi i Budapest. Flanøren sveder voldsomt og forsøger fortvivlet at sætte tempoet ned.

- De er i færd med at blive vestmenneske, Count!

Netop som han ophidset forsøger at dræbe den dampende flanør med en hvas formulering, kolliderer Count Esterházy med en tredje person, der netop drejer om hjørnet. Denne mister grebet om sin mappe.

- Diavolo!

- Beklager.

- Tak! Hvor er indgangen til foredragssalen, unge mand?

- Lige til højre, tror jeg, svarer flanøren.

Derpå vender han sig rådvildt om mod Count Esterházy.

- Eller er det til venstre?

Count Esterházy er rasende.

- Intet er sikkert mere!

Manden med mappen rækker hånden frem.

- Montemagri, Marcello. 
- Esterházy, Count.

Flanørens fremstrakte hånd hænger længe i luften, indtil den efterhånden begynder at sove.

- Parodist!

- Montemagri, De er en vidende mand, men man må også tilføje, at De er italiener og at Deres måde at omgås med Donau på er fuld af inkonsekvenser.

Flanøren træder imellem.

- Hr. Montemagri, jeg vil udtrykke min beundring for Deres encyklopædiske bog. Jeg sætter især pris på Deres ironi: for eksempel at Lukács ikke værdsatte Donau, der strømmede forbi uden for hans vinduer, fordi floden ikke havde læst Kant eller Hegel.

Fląnøren ler skabagtigt.

- Men De tager fejl, hvad Count Esterházy angår! Hans bog er ikke en parodi.

- Floden tilhører alle!

- Men hvis den ikke er en parodi, hvad er den så?

- Det hele er ikke et genrespørgsmål. De. må indse, at Count Esterházy drager andre slutninger af historien på sit sprog.

- Eklektiker!

- Turist!

Pludselig høres der en stemme i en højttaler, der er anbragt oven over knagerækkerne i korridoren.

- Marcello Montemagri, vær venlig at tage plads på podiet!

- De undskylder nok. Jeg har forberedt en tale.

De tager begge et skridt fremad og kolliderer i døråbningen.

- Corpo di Bacco!

- Montemagri, Deres bog tilhører Donau, men min bog tilhører litteraturen.

Videnskabsakademiets store sal er i baggrunden dækket af en mægtig banderole med påskriften „Opsving øst““. På podiet sidder Jean Dérelier, Kisel Kobra, Checker Kilosz, Paul Fellow, Monsieur Conderat, Marcello Montemagri og Count Esterházy. På talerstolen står professor Anklang.

- ...skal føre til ét stort fælles europæisk institut. Og dermed byder jeg Dem hjerteligt velkommen til anden dags foredrag. Hr. Montemagri foretager allerførst en sammenfatning af gårsdagens diskussion.

- Signore, signori, hvis man er alt for realistisk, ser man kun det nærværende og ikke den sande virkelighed. Hvis vi tager vores udgangspunkt i Donaus undervegetation, dens mudrede flodbund, ser vi, at der i øjeblikket faktisk flyder diverse ubehageligheder op til overfladen, grimme fisk, som vi troede for længst var forgiftede...

Det skratter voldsomt i højttalerne. Afslutningsvis høres der et kort koncist knald. Efter et kort øjebliks tumult træder en mand i overalls og med megafon hen til podiet.

- Der er opstået en teknisk fejl. Vi fra General Motors' sponsorteam beklager det indtrufne og beder Dem have en smule tålmodighed.

Count Esterházy skynder sig med forlegen mine ud $\mathrm{i}$ en af korridorerne, åbenbart $\mathrm{i}$ den hensigt at opsøge et afsides beliggende sted til en stunds filosoferen. Netop som han efter en halv times tid i de rolige og ophøjede sfærer vender tilbage fra herretoilettet, skratter det igen i en af de højttalere, der hænger ude i korridoren.

- Den intellektuelle har altid været en systematisk person. Han forsøger at skabe et system eller et antisystem. Forfatteren derimod drives af en lyrisk følelse for sproget. Han forsøger at fortælle en historie, og den har hurtigt sin egen vilje.

Pludselig făr Count Esterházy øje på en ung kvinde, der snor sit hår $\mathrm{i}$ en knude, men så med ét bliver træt og slipper det fri med en latter. Hun har et af de ansigter, man aldrig glemmer, og greven bliver melankolsk stående. Han hører end ikke Monsieur Conderats stemme, men drømmer om sin ungdom. Ansigtet udslettes pludselig, og han føler sig løst af skriveriets band. Det føles, som om han står over for det, der ikke kan skrives, og at dette er mere værd end alt andet, uantastet. Han kan ikke slippe Anna Blume med blikket.

Det klinger fra højttaleren.

- Hvis romanen virkelig må forsvinde, skyldes det ikke, at den skulle have udtømt sine kræfter, men at den befinder sig $\mathrm{i}$ en verden, der ikke længere har plads til den. 
Anna Blume er hensunket i tanker. Var det Primo Levi, der skrev, at accepten af ordenes udhuling og meningstab er ensbetydende med forudanelsen om den endelige ligegladhed?

Da det igen skratter i højttaleren, får hun øje på Count Esterházy, som hun i det øjeblik tager for en gammel vis mand.

- Marx havde i hvert fald ret i, at alle forhold mellem mennesker ville blive behersket af egennytte og derpå efterhånden opløses.

Anna Blume synes, at manden med det gråsprængte hårpur ser sørgmodig ud og sender ham et af sine indbydende smil, hvilket fører til, at Count Esterházy kejtet bliver stående foran hende uden at høre et eneste af Paul Fellows betydningsfulde ord.

- De nye teknologier medfører en overgang til helt andre livsformer, men det betyder ikke, at min livsform ikke kan rumme en mulighed for at modstå overgangen. Osip Mandelstam forblev sin livsform tro. Hvis bare ti procent af befolkningen forholdt sig på lignende måde, ville vi have en agtværdig offentlighed.

- Nu må det snart være Kisel Kobras tur, siger Anna Blume leende.

Det skratter.

- Nu kan vi være rolige eller ulykkelige af egen kraft.

- Eller Monsieur Conderat, siger Count Esterházy og fisker en cigaret op.

En stemme med en mærkelig fransk accent.

- Intet er så svært at forstå som humoren. Alt, hvad den rører ved, gør den tvetydigt. Den er det guddommelige lyn, som afslører verdens moralske tvetydighed og menneskets grundige mangel på beføjelse til at dømme andre; humoren: beruselsen i de menneskelige tings relativitet; den gådefulde nydelse $i$ visheden om, at der ikke gives nogen vished.

- Har De ild?

Anna Blume kigger underfundigt på Count Esterházy, mens hun selv tænder en cigaret og derpå smider tændstikæsken hen til ham.

- Jeg kunne godt lide det, De sagde om os kvinder. Hvordan var det nu: Litteraturen bekræfter den nøgne... tankefulde... kvindelighed, og så - hvis ideer skal vækkes af erfaringen.
Count Esterházy pulser nervøst på sin cigaret, en vareprøve af mærket Gauloises.

- Slet ikke! ...den nøgne rædselsfulde... timelighed, som vækker behovet for erfaring. Nå ja, Deres variant var måske bedre. De blander mine temaer sammen. Somme tider spørger jeg faktisk mig selv, hvad mine temaer er. Jeg har skrevet jeg ved ikke hvor mange bøger. Men det er ikke mine temaer, der er vigtige. Det lyder måske forfærdeligt; det ville formentlig være godt, hvis man havde et veldefineret tema eller ligefrem en handling. Det ville være endnu bedre!

Anna Blume beundrer alvoren i hans udlægning; hun aner en dunkel erfaring $i$ den engagerede ældre mands akribiske svada. Count Esterházy ler pludselig skingert, som om han på psykologisk institut demonstrerede et anfald af hysteri.

- At have lidt handling, det ville virkelig være herligt! En handling og en hovedperson. Herregud, giv mig lidt handling! Montemagris foredrag var faktisk ikke så tosset. Men hvad ved han om, hvordan vi ungarer slynger ungarske ord $\mathrm{i}$ hovedet på hinanden. At tale om Donau er for mig ensbetydende med at skrive en sonet, det er altså en form. Det har med fortællingens problem at gøre. Jeg kan lide givne former og det, man kan gøre med dem. Den, der skriver, sætter stiger op, bruger mørtel og puds. Når jeg fjerner disse hjælpemidler, står der forhåbentlig noget tilbage: et sprogligt rum omkring personerne.

- Er det personer fra livet?

- Nej, nej, nej, men naturligvis stammer de fra erfaringer af en eller anden art.

Kisel Kobras stemme skratter ud af højttaleren.

- Det, vi ser rundt om os, er en ny Balzacæra.

Count Esterházy går leddeløst frem og tilbage foran Anna Blume, som om han vil overbevise hende om en vis fysisk dagsform.

- Visse forfattere ved, hvad deres personer foretager sig uden for romantiden. Men det gør jeg ikke! De eksisterer ikke, de er bare ord. Men hvis de bare var ord, ville de være uinteressante! Selv mine følelser sammensættes følgelig af ord. Donaubogen begynder jo som en familieroman, sådan forsøger jeg altid at starte, men derefter bliver det mere forvir- 
ret, og alt andet er umuligt; det har også noget at gøre med min længsel. Man skal fortælle uden at lyve.

- Er hver ny bog, De skriver, ikke et forhæng mellem Dem og verden? Hvem er egentlig Deres arbejdsgiver?

Count Esterházy bliver stående som forstenet. Pludselig roder han fortvivlet i sin gamle lædertaske og tager en gammel rejseskrivemaskine op, som han ryster voldsomt. Han har svedperler på panden, og Anna Blume fortryder allerede sit lille nummer. Hvorfor laver hun halløj med ham, mens han sprænges af sine modsigelser?

- En sand forfatter, ville det ikke være en, der nægter at skrive nogen bog?

Anna Blume forsøger at hidse ham ned med et neutralt spørgsmål.

- De beskrev jo lige i Deres tale, hvordan De sammen med nogle andre ungarske forfattere boykotter radio og tv-kanalerne, fordi den nye magt misbruges dér. Hvordan reagerer de ansvarlige egentlig?

- De er ikke bare ligeglade; det glæder dem. Vicepræsidenten på radioen udtrykker en uhæmmet sympati for vores aktion. Han håber, den kommer til at omfatte hele vores epoke.

Anna Blume griber fat i Count Esterházys jakkeopslag, som om hun var ved at drukne, hvilket et øjeblik făr ham til at miste balancen.

- De skal skrive, skrive, skrive; det brøler Deres livsopgave til Dem!

- Friheden i skriveriet indeholder en slavisk fuldførelse. Og alligevel snakker forfatteren altid om nederlaget, om det svage, om tavsheden. En bog er egentlig et udtryk for tavshedens tale. Jeg sidder ikke otte-ti timer dagligt på mit værelse, fordi jeg tror, der er mere liv dér end på Bahamaøerne, men fordi det har vist sig, at jeg har det bedst dér. Det kan være, at der er et eller andet her, der ikke stemmer, men jeg har ikke noget valg. Hvis jeg havde et valg, kunne jeg tænke mig om.

- De sidder altså normalt lukket inde på Deres værelse i udkanten af Budapest i otte-ti timer om dagen som følge af lystprincippet. De er sandelig et dpræget nydelsesmenneske, min herre!
Han ville gerne strække tiden, lægge hovedet bagover og bare drikke den latter. Bliver han holdt for nar? Driver hun gæk med ham? Egal!

- På forlaget kalder de mig „Hr. på den ene side“ eller „Hr. på den anden side“. Jeg synes simpelt hen, det er mistænkeligt, hvis en forfatter har noget at sige. Der er jo en herlig sætning: hvis du kommer på noget, så gå frem og tilbage lidt, indtil det er gået over. Men hvis bogen ikke har noget at sige, så læser jeg den ikke. Så er den uinteressant. Kan De sige mig hvorfor?

- Vi står over for litteraturens grundlæggende paradoks!

- Ja, det er ikke som alvidende fortæller, man skal strø krummer ud for læserne. Det drejer sig tværtimod om at opbygge noget af det, man ikke ved, som ikke er viden men erfaring - skyggen af en lidenskab.

- Så skriveriet udgår altså fra erfaringen?

De farer begge sammen, da det skratter i højttaleren.

- Jeg vil læse mine gerningers tekst; hvem er det, der har handlet i mig?

Count Esterházy smiler.

- Naturligvis.

Den unge dame har en besynderlig udstråling. Count Esterházy har for længst glemt såvel sine tandlægetider som sit alarmerende kolesteroltal.

- Hvad har De for i aften?

Det skratter i højttaleren.

- Det har altid været min ambition at forene spørgsmålets yderste alvor med formens yderste lethed.

- Jeg er desværre optaget, min herre.

Count Esterházy skuler irriteret i reming af højttaleren.

- Foreningen af en letsindig form og et alvorligt stof blotlægger vore dramaer - dem der udspiller sig i vore senge lige så vel som dem vi spiller på historiens store scene - $\mathrm{i}$ hele deres frygtelige betydningsløshed.

Anna Blume rejser sig hastigt op, og hendes stemme giver et let skrig fra sig, som synes at stamme både fra den pludseligt bemærkede stivhed og den liflige følelse af at slippe kroppen løs i én 
eneste pludselig bevægelse. Hun prikker ukyndigt med pegefingeren på den rejseskrivemaskine, der stadig dingler i Count Esterházys udstrakte hånd. Så kysser hun ham let på kinden.

- Jeg skal forlyste mig ved skrivebordet. Der er ikke noget, der kan måle sig med at trænge ind i sin egen hjerne. Var det ikke det, De sagde?

Han farer sammen. Værelset er helt mørkt nu. Manuskriptbunkerne bliver langsomt synlige, et svagt månelys siver ind fra vinduet. Han hører skridt, der nærmer sig.

På dansk ved Karsten Sand Iversen 